\title{
Explaining spatial variability in mean annual runoff in the conterminous United States
}

\author{
David M. Wolock ${ }^{1, *}$, G regory J . McC abe ${ }^{2}$ \\ ${ }^{1}$ U.S. G eological Survey, 4821 Q uail C rest Place, Lawrence, Kansas 66049, USA \\ ${ }^{2}$ U.S. G eological Survey, Denver Federal Center, MS 412, Denver, Colorado 80225, USA
}

\begin{abstract}
The hydrologic concepts needed in a water-balance model to estimate the spatial variation in mean annual runoff for the 344 climate divisions in the conterminous United States (U.S.) were determined. The concepts that were evaluated were the climatic supply of water (precipitation), climatic demand for water (potential evapotranspiration), seasonality in supply and demand, and soilmoisture-storage capacity. Most (91\%) of the spatial variability in mean annual runoff for the climate divisions in the conterminous U.S. was explained by the spatial variability of mean annual precipitation minus mean annual potential evapotranspiration. When soil-moisture-storage capacity and seasonality in supply and demand were added to the water balance, the explained variance in mean annual runoff increased slightly, and the error in estimated mean annual runoff decreased significantly. Adding soilmoisture-storage capacity and seasonality in supply and demand provided the most improvement in areas where seasonal supply and demand are out of phase.
\end{abstract}

KEY WORDS: Runoff $\cdot$ Streamflow $\cdot$ Hydrologic modeling $\cdot$ Hydroclimatology

\section{INTRODUCTION}

One of the most basic problems in hydrology is to describe and explain the spatial and temporal variability of the annual water balance, which is the partitioning of precipitation into runoff and evapotranspiration (Milly 1994). An understanding of the factors that control components of the annual water balance provides a base of knowledge of the relations between climatic and hydrologic variables. In addition, with the use of general circulation models to estimate the effects of changing climate on mean hydrologic conditions, it is essential that the factors that affect the annual water balance are understood and identified (Lettenmaier et al. 1994, Strzepek \& Yates 1997).

An important component of the annual water balance is runoff, which is defined here as flow in streams and rivers expressed on a per unit area basis. Runoff is important to researchers studying the annual water balance because it can be measured with accuracy compared to other components of the water balance

*E-mail: dwolock@usgs.gov such as precipitation and evapotranspiration. Also, runoff is a critical component of the water balance from a practical perspective because of its various uses to humans and its importance to aquatic ecosystems.

There have been numerous studies that have examined the factors that affect the temporal variability of runoff (Wigmosta \& Burges 1997, Xia et al. 1997, and Lohmann et al. 1998 are recent examples), but fewer studies have examined the factors that affect the spatial variability of runoff. Thornthwaite (1948) and Budyko (1955) used mean annual precipitation and mean annual potential evapotranspiration to identify moisture regimes on a global basis. During the same time period, Langbein (1949) described the physical factors that control the spatial distribution of annual runoff in the conterminous United States (U.S.) and found that climate was the dominant control of the spatial variability of annual runoff. Most recently, Milly \& Eagleson (1987) and M illy (1994) indicated that precipitation characteristics such as storm intensity and frequency, soil texture, vegetation type and density, and geomorphology are important factors controlling the spatial variability of annual runoff. 
The aforementioned benchmark studies have identified several fundamental concepts of the water balance: climatic supply (precipitation) and demand (potential evapotranspiration), seasonality in supply and demand, and soil-moisture storage. The objective of the study described in this paper is to determine which of these simple water-balance-model concepts are required to reasonably estimate spatial variability in mean annual runoff across the conterminous U.S. The goal of the study is not to determine the model that best represents our understanding of the physical processes affecting the annual water balance. Instead, it is to clarify which concepts must be part of a model to predict spatial variability in mean annual runoff. This objective is motivated by the need to test continentalscale hydrologic models, such as those in atmospheric general circulation models. This study shows the minimum model complexity required to reasonably simulate spatial patterns in mean annual runoff. The study also suggests some limitations in using spatial patterns of mean annual runoff for model evaluation. Model concepts that do not appreciably affect spatial patterns of mean annual runoff cannot be meaningfully tested using this variable.

\section{METHODS}

2.1. Estimation of mean annual runoff. Annual runoff was estimated using models of varied complexity and physical detail (Table 1). By using methods of increasing detail it is possible to determine how much complexity is needed to explain the spatial distribution of mean annual runoff. The models were various combinations of the principal concepts of a water-balance model that describe climatic water supply and demand, seasonality in supply and demand, and soilmoisture-storage capacity. For each model, mean annual runoff was computed by averaging annual runoff values estimated for each year in the period 1951-1980.

2.1.1. Annual precipitation: The simplest model of annual runoff is to include only the concept of water supply. This 'model' assumes that annual runoff is equal to annual precipitation.

2.1.2. Annual surplus: In addition to the supply of water, the climatic demand for water (i.e. potential evapotranspiration) also would be expected to affect spatial variability in runoff. This added component provides a basic annual water balance where annual

Table 1. Summary of methods to estimate annual runoff

\begin{tabular}{|c|c|c|c|}
\hline \multirow{2}{*}{$\begin{array}{l}\text { Estimate of annual runoff } \\
\text { Annual precipitation }\end{array}$} & & \multicolumn{2}{|l|}{ Estimate computation } \\
\hline & & $\mathrm{Q}_{\mathrm{ann}}=\mathrm{P}_{\mathrm{ann}}$ & $\mathrm{AET}_{\mathrm{ann}}=0$ \\
\hline Annual surplus & $\begin{array}{l}\text { or } \mathrm{P}_{\mathrm{ann}}>\mathrm{PET}_{\mathrm{ann}} \\
\text { or } \mathrm{P}_{\mathrm{ann}} \leq \mathrm{PET}_{\mathrm{ann}}\end{array}$ & $\begin{array}{l}\mathrm{Q}_{\mathrm{ann}}=\mathrm{P}_{\mathrm{ann}}-\mathrm{PET} \text { ann } \\
\mathrm{Q}_{\mathrm{ann}}=0\end{array}$ & $\begin{array}{l}\mathrm{AET}_{\mathrm{ann}}=\mathrm{PET}_{\mathrm{ann}} \\
\mathrm{AET}_{\mathrm{ann}}=\mathrm{P}_{\mathrm{ann}}\end{array}$ \\
\hline \multirow[t]{2}{*}{ M onthly surplus } & & $\mathrm{Q}_{\mathrm{ann}}=\sum_{\mathrm{i}=1}^{12} \mathrm{~S}_{\mathrm{i}}$ & $A E T_{a n n}=\sum_{i=1}^{12} A E T_{i}$ \\
\hline & $\begin{array}{l}\text { or } \mathrm{P}_{\mathrm{i}}>\mathrm{PET}_{\mathrm{i}} \\
\text { or } \mathrm{P}_{\mathrm{i}} \leq \mathrm{PET}_{\mathrm{i}}\end{array}$ & $\begin{array}{l}S_{i}=P_{i}-P E T_{i} \\
S_{i}=0\end{array}$ & $\begin{array}{l}A E T_{i}=P E T_{i} \\
A E T_{i}=P_{i}\end{array}$ \\
\hline \multirow[t]{2}{*}{$\begin{array}{l}\text { M onthly surplus and } \\
\text { constant or variable storage capacity }\end{array}$} & & $Q_{a n n}=\sum_{i=1}^{12} S_{i}$ & $A E T_{a n n}=\sum_{i=1}^{12} A E T_{i}$ \\
\hline & or $\mathrm{P}_{\mathrm{i}} \leq \mathrm{PET}_{\mathrm{i}}$ & \multicolumn{2}{|c|}{$\begin{array}{l}\mathrm{SMR}_{\mathrm{i}}=\text { the lesser of }\left(\mathrm{SM}_{\text {cap }}-\mathrm{SM}_{\mathrm{i}}\right) \text { or }\left(\mathrm{P}_{\mathrm{i}}-\mathrm{PET}_{\mathrm{i}}\right) \\
\mathrm{SM}_{\mathrm{i}+1}=\mathrm{SM}_{\mathrm{i}}+\mathrm{SMR}_{\mathrm{i}} \\
\mathrm{S}_{\mathrm{i}}=\mathrm{P}_{\mathrm{i}}-\mathrm{PET}_{\mathrm{i}}-\mathrm{SMR}_{\mathrm{i}} \\
\mathrm{AET}_{\mathrm{i}}=\mathrm{PET}_{\mathrm{i}} \\
\mathrm{S}_{\mathrm{i}}=0 \\
\mathrm{SMR}_{\mathrm{i}}=0 \\
\mathrm{AET}_{\mathrm{i}}=\mathrm{P}_{\mathrm{i}}+\mathrm{SM}_{\mathrm{i}} / \mathrm{SM}_{\text {cap }} \times\left(\mathrm{PET}_{\mathrm{i}}-\mathrm{P}_{\mathrm{i}}\right) \\
\mathrm{SM}_{\mathrm{i}+1}=\mathrm{SM}_{\mathrm{i}}-\mathrm{AET}_{\mathrm{i}}\end{array}$} \\
\hline \multicolumn{4}{|l|}{ Variable definitions: } \\
\hline $\begin{aligned} \mathrm{AET}_{\mathrm{ann}} & =\text { annual actual evapotranspiration } \\
\mathrm{AET}_{\mathrm{i}} & =\text { actual evapotranspiration for month } \mathrm{i} \\
\mathrm{P}_{\mathrm{ann}} & =\text { annual precipitation } \\
\mathrm{P}_{\mathrm{i}} & =\text { precipitation for month } \mathrm{i} \\
\mathrm{PET}_{\mathrm{ann}} & =\text { annual potential evapotranspiration } \\
\mathrm{PET}_{\mathrm{i}} & =\text { potential evapotranspiration for month }\end{aligned}$ & \multicolumn{3}{|c|}{$\begin{aligned} Q_{\text {ann }} & =\text { annual runoff } \\
S_{i} & =\text { surplus for month } \mathrm{i} \\
S M_{\text {cap }} & =\text { soil-moisture-storage capacity } \\
S M_{i} & =\text { soil-moisture storage for month } \mathrm{i} \\
S M_{i+1} & =\text { soil-moisture storage for the next month } \\
S M R_{i} & =\text { soil-moisture recharge for month } \mathrm{i}\end{aligned}$} \\
\hline
\end{tabular}


runoff is estimated by the surplus of annual precipitation that is in excess of annual potential evapotranspiration. In this model, annual runoff is assumed to be equal to zero if annual potential evapotranspiration is greater than annual precipitation. This is equivalent to assuming that annual actual evapotranspiration is equal to annual potential evapotranspiration to the extent that annual precipitation is sufficient to meet the climatic demand.

2.1.3. Monthly surplus: The climatic supply and demand for water at a location vary through the year and do not necessarily covary; thus, the timing of these 2 factors may be important to develop accurate estimates of mean annual runoff. The concept of seasonal timing of water supply and demand was included in an estimate of mean annual runoff by summing the monthly surplus values of precipitation minus potential evapotranspiration. In this conceptual model, annual runoff is estimated by the sum of monthly precipitation that is in excess of monthly potential evapotranspiration computed on a month-by-month basis. This model assumes that monthly actual evapotranspiration is equal to monthly potential evapotranspiration to the extent that monthly precipitation is adequate to meet the climatic demand.

2.1.4. Monthly surplus and storage: Soil-moisture storage provides a reservoir of moisture that is available to plants and is an important factor affecting actual evapotranspiration. In this conceptual model, when precipitation for a month is less than potential evapotranspiration, then actual evapotranspiration is equal to precipitation plus the amount of moisture that can be removed from the soil. The fraction of soil-moisture storage that can be removed decreases linearly with decreasing soil-moisture storage; that is, as the soil becomes drier, water becomes more difficult to remove from the soil and less is available for actual evapotranspiration. When precipitation exceeds potential evapotranspiration in a given month, actual evapotranspiration is equal to potential evapotranspiration; water in excess of potential evapotranspiration replenishes the soil-moisture storage. When the soil moisture storage reaches capacity in a given month, the excess water becomes runoff. Soil-moisture-storage capacity was included with monthly surplus to estimate annual runoff in 2 ways: (1) a single value for soil-moisture-storage capacity was used for all climate divisions, and (2) a variable soil-moisture-storage capacity derived from soil data was used for the climate divisions.

2.2. Potential evapotranspiration. Potential evapotranspiration was calculated using the Hamon equation (Hamon 1961). The Hamon equation is

$$
\mathrm{PET}_{\text {Hamon }}=13.97 \mathrm{dD}^{2} \mathrm{~W}_{\mathrm{t}}
$$

where $\mathrm{PET}_{\text {Hamon }}$ is Hamon potential evapotranspiration in $\mathrm{mm}$ per month, $\mathrm{d}$ is the number of days in a month, $D$ is the mean monthly hours of daylight in units of $12 \mathrm{~h}$, and $\mathrm{W}_{\mathrm{t}}$ is a saturated water vapor density term calculated by

$$
\mathrm{W}_{\mathrm{t}}=\frac{4.95 \mathrm{e}^{0.062 \mathrm{~T}}}{100}
$$

where $\mathrm{T}$ is the monthly mean temperature in ${ }^{\circ} \mathrm{C}$. In this study, potential evapotranspiration was set to zero when mean monthly temperature was $-1^{\circ} \mathrm{C}$ or lower. This model has been used successfully to estimate monthly and annual potential evapotranspiration for various parts of the conterminous U.S. (Hamon 1961).

2.3. Temperature, precipitation, and runoff data. Monthly temperature and precipitation data were obtained for the 344 climate divisions in the conterminous U.S. (Fig. 1). The climate divisions represent regions within states that are, as nearly as possible, climatically homogeneous (Karl \& Riebsame 1984). In addition, the data for the climate divisions have been corrected for time-of-observation bias (Karl et al. 1986). Although extreme climatic variations can occur in areas of complex terrain, such as the mountainous areas of the western U.S., standardized departures of temperature and precipitation from normal are spatially consistent within a climate division (Karl \& Riebsame 1984). Monthly temperature and precipitation data for water years 1951-1980 were used as inputs to the models.

Mean annual runoff data for each climate division were obtained from the data set produced by Gebert et al. (1987). Gebert et al. mapped contours of mean annual runoff over the conterminous U.S. for the period 1951-1980. These values were determined from records of measured streamflow at 5951 gauging stations. Streamflows at these gauging stations were considered by Gebert et al. to be natural (i.e. unaffected by upstream reservoirs or diversions) and representative of local conditions. For this study, the contours of mean annual runoff produced by Gebert et al. were interpolated onto a $5 \mathrm{~km}$ by $5 \mathrm{~km}$ grid using a geographic information system. The gridded values then were used to calculate mean annual runoff for each of the 344 climate divisions (Fig. 2). Among the 344 climate divisions, mean annual runoff ranged from 23 to $2530 \mathrm{~mm}$, the mean value was $324 \mathrm{~mm}$, and the 25th and 75th percentile values were 77 and $475 \mathrm{~mm}$, respectively.

2.4. Soil-moisture-storage capacity data. Mean soilmoisture-storage capacity was determined for each of the 344 climate divisions from the State Soil Geographic Data Base (STATSGO) data set (U.S. Department of A griculture 1993). The STATSGO data set contains generalized soil property data on 1:250000-scale 


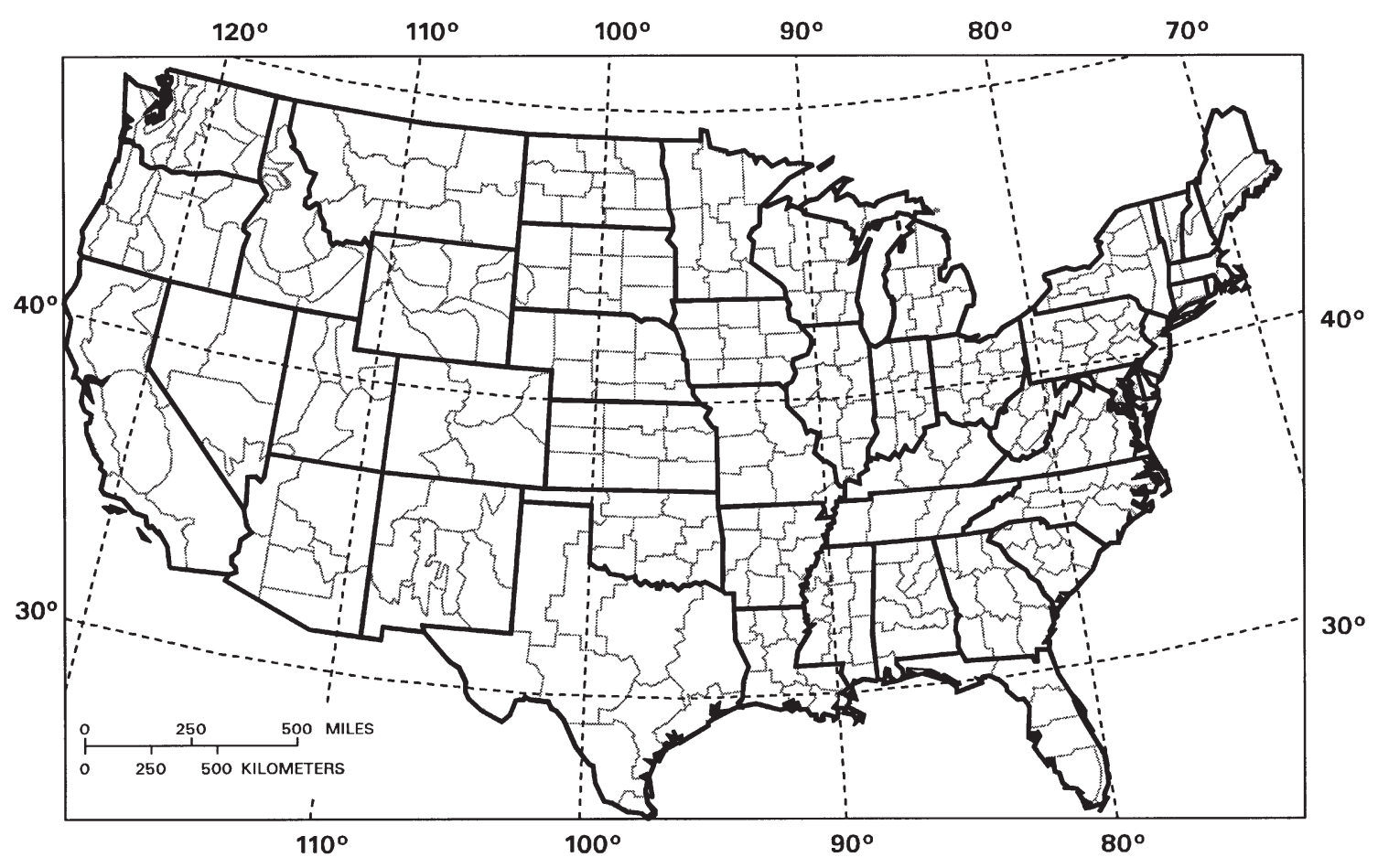

Fig. 1. The 344 climate divisions in the conterminous United States

base maps. Soil-moisture-storage capacity was computed as the product of soil thickness and the fraction of the soil volume per unit depth that contains water when saturated. The values ranged from 60 to $309 \mathrm{~mm}$, with a mean of $178 \mathrm{~mm}$. The 25th and 75th percentile values were 140 and $217 \mathrm{~mm}$, respectively.

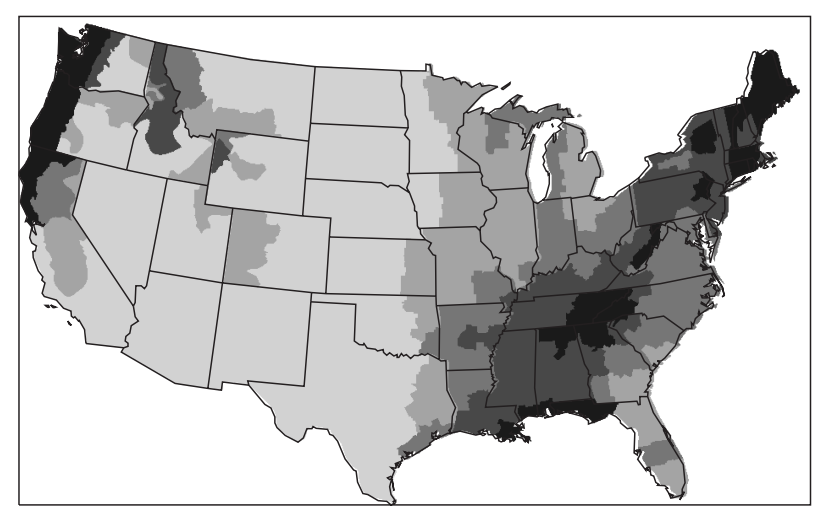

Measured runoff (mm)

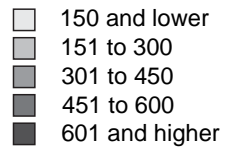

Fig. 2. Measured mean annual runoff in millimeters ( $\mathrm{mm}$ ) for the 344 climate divisions in the conterminous U.S.
2.5. Model evaluation. Measured and estimated mean annual runoff were compared using the coefficient of determination, mean absolute error, bias, and the Nash-Sutcliffe coefficient of efficiency.

The coefficient of determination $\left(R^{2}\right)$ describes the proportion of the total variance in the measured data that can be explained by the model. It ranges from 0 (poor model) to 1 (perfect model) and is given by

$$
R^{2}=\left\{\frac{\sum_{j=1}^{N}\left(M_{j}-\bar{M}\right)\left(E_{j}-\bar{E}\right)}{\left[\sum_{j=1}^{N}\left(M_{j}-\bar{M}\right)^{2}\right]^{0.5}\left[\sum_{j=1}^{N}\left(E_{j}-\bar{E}\right)^{2}\right]^{0.5}}\right\}^{2}
$$

where $M_{j}$ is the measured value for climate division $\mathrm{j}$ and $E_{\mathrm{j}}$ is the estimated value for climate division $\mathrm{j}$; $\overline{\mathrm{M}}$ and $\overline{\mathrm{E}}$ are the respective measured and estimated means for the entire conterminous U.S., and $\mathrm{N}$ is the number of climate divisions. Note, however, that $\mathrm{R}^{2}$ is limited because it standardizes for differences between the measured and estimated means and variances. It can be easily demonstrated that if

$$
E_{j}=A M_{j}+B
$$

for any nonzero value of $A$ and any value of $B$, then $R^{2}$ $=1$. Thus, $R^{2}$ is insensitive to additive and proportional differences between model estimates and measurements (see Willmott 1984). 
To evaluate the magnitude of differences between measured and estimated values, the mean absolute error (MAE) and bias (BIAS) were computed. The MAE is computed simply as the sum of the absolute differences between measured and estimated values at each climate division divided by $\mathrm{N}$, and the BIAS is computed as $\bar{E}$ minus $\bar{M}$.

The Nash-Sutcliffe coefficient of efficiency has been widely used to evaluate the performance of hydrologic models (e.g. Leavesley et al. 1983, Wilcox et al. 1990). Nash \& Sutcliffe (1970) defined NS, which ranges from minus infinity (poor model) to 1 (perfect model), as

$$
N S=1-\frac{\sum_{j=1}^{N}\left(M_{j}-E_{j}\right)^{2}}{\sum_{j=1}^{N}\left(M_{j}-\bar{M}\right)^{2}}
$$

NS is the ratio of the mean absolute error to the variance in the measured data subtracted from unity. If the square of the differences between measurements and model estimates is as large as the variability in the measured data then NS $=0$; if the square of the differences exceeds the variability in the measured data then NS $<0$. Thus, a value of zero for NS indicates that the measured mean, $\bar{M}$, is as good a predictor as the model, while negative values indicate that the measured mean is a better predictor than the model (Wilcox et al. 1990). The coefficient of efficiency is an improvement over $\mathrm{R}^{2}$ for model evaluation purposes because it is sensitive to differences in the measured and modelestimated means and variances; that is, NS decreases as $A$ and $B$ in Eq. (4) deviate from 1 and 0 , respectively. Due to the squared differences, however, NS is sensitive to extreme values, as is $\mathrm{R}^{2}$.

\section{RESULTS AND DISC USSION}

\subsection{Annual precipitation (Fig. 3A)}

A comparison of mean annual runoff with mean annual precipitation produced an $\mathrm{R}^{2}$ of 0.64 (Table 2 , Fig. 4A). Over half of the spatial variability in mean annual runoff is explained by the spatial variability in the supply of water (mean annual precipitation). On

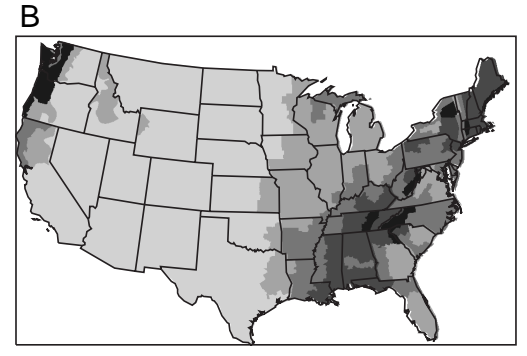

Annual surplus (mm)

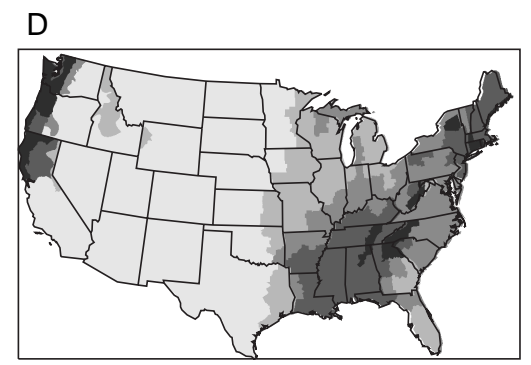

Constant storage $(\mathrm{mm})$

Estimated runoff (mm)

50 and lower

151 to 300

301 to 450

451 to 600

601 and higher

Variable storage $(\mathrm{mm})$

Fig. 3. Estimated mean annual runoff. Estimators used: (A) annual precipitation, (B) annual surplus, (C) monthly surplus, (D) monthly surplus and constant storage and (E) monthly surplus and variable storage

average, however, mean annual precipitation overestimates mean annual runoff ( $\mathrm{MAE}=557 \mathrm{~mm}$ and $\mathrm{BIAS}=$ $556 \mathrm{~mm})$. NS is negative $(-3.24)$ because of the large error in the estimates of mean annual runoff; the negative NS value indicates that average mean annual runoff for the conterminous U.S. is a better predictor of mean annual runoff across the U.S. than is mean annual precipitation. Mean annual precipitation overestimates mean annual runoff almost everywhere in the conterminous U.S. (Fig. 5A).

\subsection{Annual surplus (Fig. 3B)}

When the surplus of annual precipitation over annual potential evapotranspiration is used to estimate mean annual runoff, $\mathrm{R}^{2}$ increased to 0.91 (Table 2, Fig. 4B). MAE decreased to $77 \mathrm{~mm}$; on average, climate division 


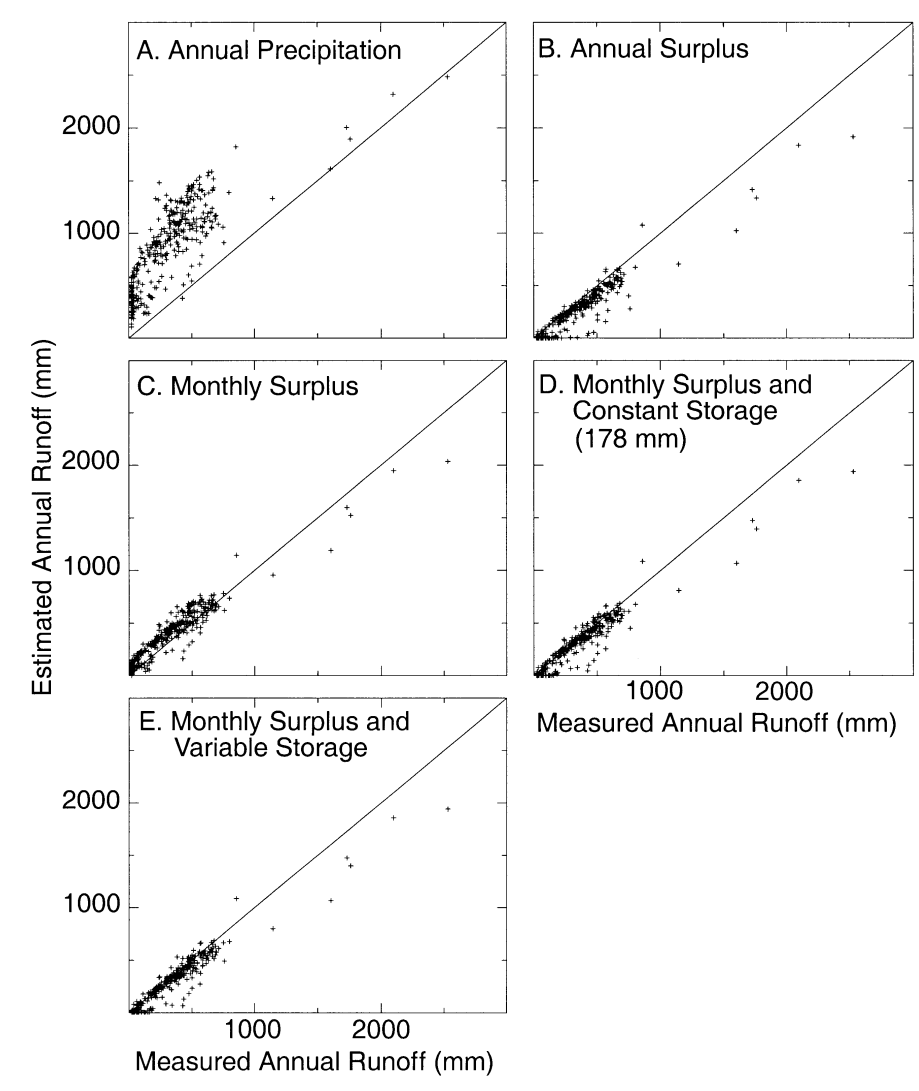

Fig. 4. Scatterplots of estimated and measured mean annual runoff. Estimators used: as in Fig. 3. Solid diagonal line: perfect agreement between estimated and measured values

values of annual surplus underestimate mean annual runoff (BIAS $=-73 \mathrm{~mm}$ ). The magnitude of the underestimation is greatest in mountainous areas of the western U.S. and in the south-central and northeastern U.S. (Fig. 5B). NS increased to 0.84, indicating that the annual surplus model is a better predictor of mean annual runoff than mean annual precipitation.

\subsection{M onthly surplus (Fig. 3C)}

This model includes information about the seasonal distribution of the supply of water (precipitation) and the seasonal climatic demand for water (potential evapotranspiration) at each location. The $\mathrm{R}^{2}$ value for this model was 0.91 (Table 2, Fig. 4C), which is the same as the $R^{2}$ for the annual surplus model. The MAE $(90 \mathrm{~mm})$ for the monthly surplus model is slightly larger than the MAE for the annual surplus model. In contrast to annual surplus, the monthly surplus model generally overestimates mean annual runoff (BIAS $=64 \mathrm{~mm}$ ). The overestimation is greatest in the central and southeastern U.S. (Fig. 5C). In contrast, the monthly surplus model underestimates runoff in parts of the northwestern U.S. where measured annual runoff is very high (i.e. greater than $1000 \mathrm{~mm}$ ). The NS value for the monthly surplus model is 0.86 , which is only a small increase over the annual surplus model. These results indicate that information regarding the seasonality of precipitation and potential evapotranspiration alone does not contribute to a significantly improved model of the spatial distribution of mean annual runoff.

\subsection{Monthly surplus and constant storage (Fig. 3D)}

The inclusion of soil-moisture storage (using the mean soil-moisture-storage capacity of $178 \mathrm{~mm}$ for the conterminous U.S.) in the monthly surplus model did not result in a significant increase in explained variance $\left(R^{2}=0.92\right)$ compared to using annual surplus or monthly surplus models (Table 2, Fig. 4D). The addition of a constant soilmoisture storage, however, did result in an improved

Table 2. Statistics describing comparisons of estimated and measured mean annual runoff. BIAS is computed as average estimated mean annual runoff minus measured mean annual runoff. The constant soil-moisture storage value was $178 \mathrm{~mm}$. This is the mean soil-moisture-storage capacity computed from the U.S. Department of Agriculture's (1993) State Soil Geographic Data Base (STATSGO) data set for the conterminous U.S.

\begin{tabular}{|c|c|c|c|c|}
\hline $\begin{array}{l}\text { Estimate of mean } \\
\text { annual runoff }\end{array}$ & $\begin{array}{c}\text { Coefficient of } \\
\text { determination }\left(\mathrm{R}^{2}\right)\end{array}$ & $\begin{array}{l}\text { M ean absolute } \\
\text { error }(\mathrm{MAE})(\mathrm{mm})\end{array}$ & BIAS (mm) & $\begin{array}{l}\text { Nash-Sutcliffe } \\
\text { statistic (NS) }\end{array}$ \\
\hline Annual precipitation & 0.64 & 557 & +556 & -3.24 \\
\hline Annual surplus & 0.91 & 77 & -73 & 0.84 \\
\hline M onthly surplus & 0.91 & 90 & +64 & 0.86 \\
\hline $\begin{array}{l}\text { M onthly surplus and } \\
\text { constant storage }\end{array}$ & 0.92 & 58 & -40 & 0.90 \\
\hline $\begin{array}{l}\text { M onthly surplus and } \\
\text { variable storage }\end{array}$ & 0.93 & 54 & -38 & 0.91 \\
\hline
\end{tabular}


A

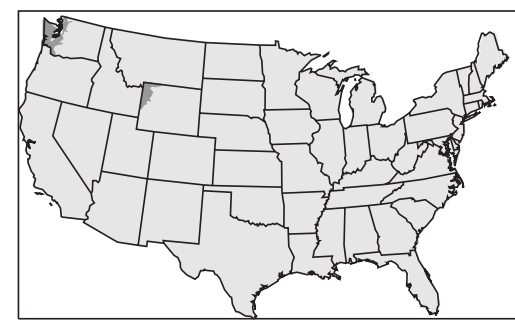

Annual precipitation - Measured runoff $(\mathrm{mm})$

$\mathrm{C}$

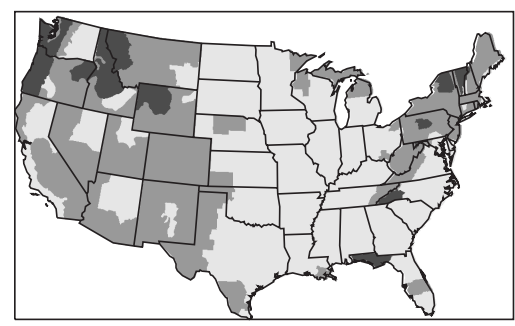

Monthly surplus - Measured runoff $(\mathrm{mm})$

E

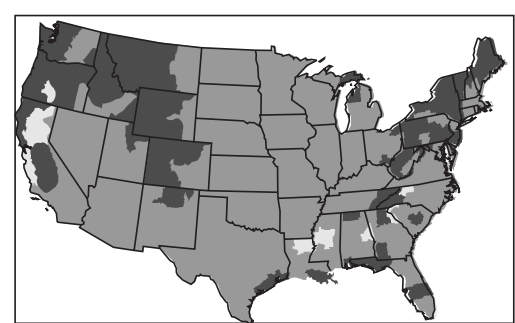

Variable storage - Measured runoff $(\mathrm{mm})$

Fig. 5. Difference between estimated and measured mean annual runoff. Estimators used: as in Fig. 3

MAE (58 mm) and BIAS (-40 mm). Also, the NS value for the monthly surplus and storage model was higher $(0.90)$ compared to the other models. The spatial extent of areas with small differences between measured and estimated runoff is large (Fig. 5D). However, the model does underestimate runoff in parts of the mountainous western U.S. and in the northeastern U.S.

\subsection{M onthly surplus and variable storage (Fig. 3E)}

Including spatially variable soil-moisture-storage capacities did not result in better estimates of mean annual runoff compared to using a constant soil-moisture-storage capacity (Table 2, Fig. 4E). The $\mathrm{R}^{2}(0.93)$, MAE $(54 \mathrm{~mm})$, BIAS (-38 mm), and NS (0.91) statistics are similar to the monthly surplus and constant storage model. The spatial pattern of differences between measured and estimated runoff also is similar to that of the constant storage model (Fig. 5E).

\subsection{Predictive value of water- balance concepts}

The simplest model that explains most of the spatial variability in mean annual runoff is the annual surplus model, which estimates annual runoff as the amount of annual precipitation that is in excess of annual potential evapotranspiration. The $\mathrm{R}^{2}$ value, which by definition gives the percent of variance in the measured data explained by the model, increased from 0.91 to only 0.93 as additional model concepts were added (Table 2 ). Therefore, the variance in mean annual runoff for the conterminous U.S. can be attributed simply to the balance between annual supply and demand.

Although the balance between annual supply and demand explains the observed spatial variability in mean annual runoff, an improved model (based on MAE, BIAS, and NS statistics) is obtained when additional water-balance concepts are added. The annual surplus model underestimates mean annual runoff on average (Table 2, Fig. 4B), and the amount of error decreases when both soil-moisture storage and seasonality in supply and demand are included in the model. When the soil-moisture-storage concept is not included, there is almost no benefit to including seasonality in supply and demand. The importance of soil-moisture-storage capacity and seasonality in supply and demand in estimating mean annual runoff identified in this study is consistent with Milly's findings for the eastern U.S. (Milly 1994).

Estimates of runoff from the annual surplus model represent the smallest amount of runoff that can occur for a given combination of precipitation and potential evapotranspiration. This model structure assumes that the entire annual supply of water is subject to the entire annual demand. Adding soil-moisture storage and seasonality in supply and demand increases the amount of estimated runoff, particularly in the southcentral U.S. and some regions in the western U.S. (Fig. 6A shows the difference in runoff between the annual surplus model and the monthly surplus model with constant soil-moisture storage.) The areas where there are increases in runoff coincide with climate divisions where the seasonal supply and demand of water 
A

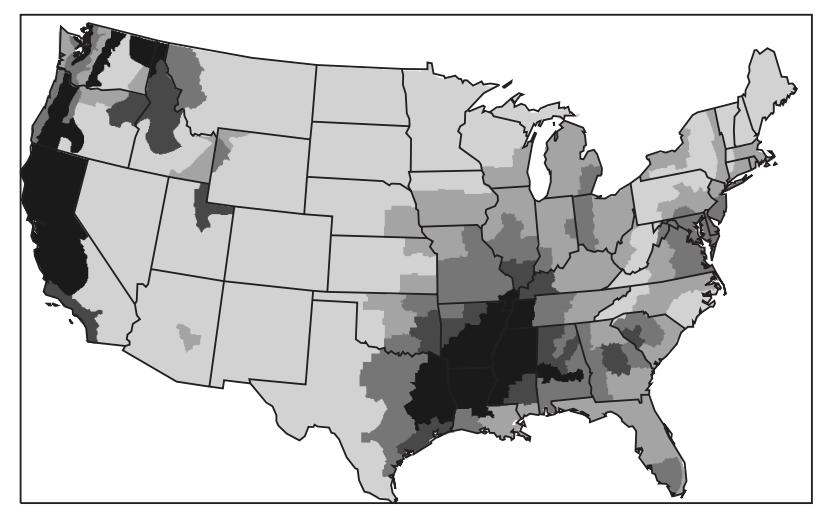

Constant storage - Annual surplus (mm)

$\begin{array}{ll}\square & 20 \text { and lower } \\ & 21 \text { to } 40 \\ & 41 \text { to } 60 \\ & 61 \text { to } 80 \\ \square & 80 \text { and higher }\end{array}$

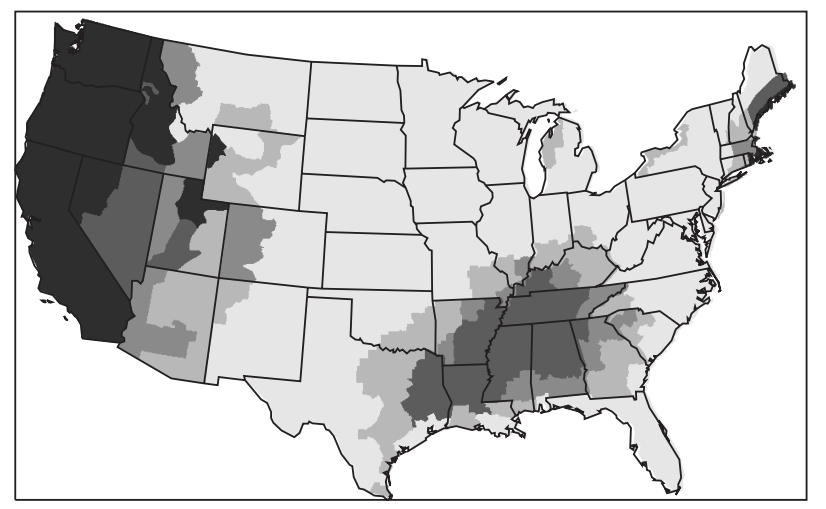

Correlation between monthly precipitation and temperature

$\square-0.61$ and lower
$\square-0.60$ to -0.21
$\square-0.20$ to 0.20
$\square-21$ to 0.60
$\square \quad 0.61$ and higher

Fig. 6. (A) Difference in runoff between the annual surplus model and the monthly surplus model with constant soil-moisture-storage capacity, and (B) the correlation between mean monthly precipitation and temperature for each climate division

are most out of phase with each other (negative correlation coefficients in Fig. 6B). The lack of synchronization of supply and demand causes runoff to occur when seasonal precipitation is high but potential evapotranspiration is low, such as in the winter months in the western U.S. Adding soil-moisture storage and seasonality in supply and demand improves the agreement between estimated and measured runoff in parts of the U.S. where climatic supply and demand are out of phase (negative correlation coefficients in Fig. 6B), but these concepts have little effect in sections of the coun-

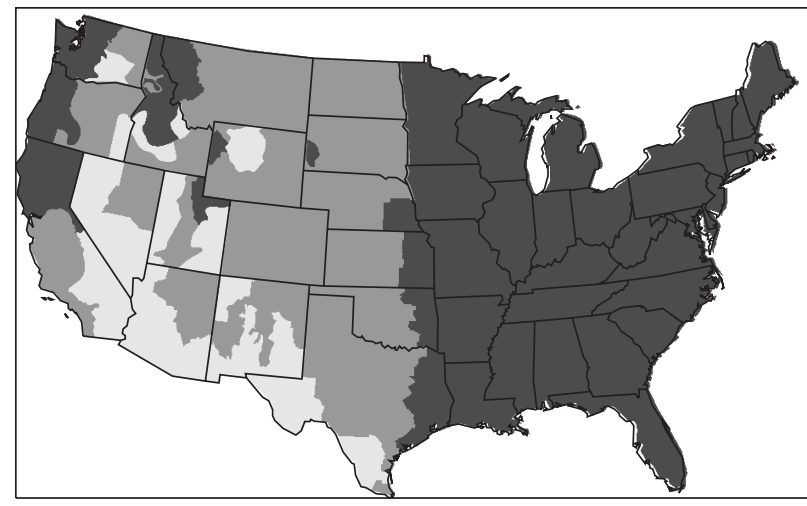

Index of dryness [Potential evapotranspiration / Precipitation]

$$
\begin{aligned}
& 1.00 \text { and lower } \\
& 1.01 \text { to } 2.00 \\
& 2.01 \text { and higher }
\end{aligned}
$$

Fig. 7. Dryness index (potential evapotranspiration/precipitation) for the conterminous U.S. Dryness index values less than 1 indicate a humid climate, and dryness index values greater than 1 indicate an arid climate. Potential evapotranspiration was estimated using the Hamon equation (Eq. 1)

try where supply and demand are in phase (positive correlation coefficients in Fig. 6B).

The relation between climatic demand for water (potential evapotranspiration, PET) and climatic supply (precipitation, PPT) can be expressed in terms of an index of dryness (Budyko 1974, Milly 1994), which is the ratio of PET to PPT. Regions with an index of dryness less than 1 can be considered humid; regions with a dryness index greater than 1 can be termed arid. The spatial pattern of the dryness index (Fig. 7) shows humid climate divisions in the eastern half of the conterminous U.S. and in a few parts of the western U.S. The remainder of the climate divisions are arid.

When the index of dryness (PET/PPT) is plotted against the ratio of actual evapotranspiration to precipitation for the climate divisions in the conterminous U.S. (Fig. 8A), an upper boundary on the points is apparent (the dashed and dotted lines). (Points above the boundary line indicate errors in measured precipitation or runoff.) This boundary is the upper limit on the fraction of precipitation that can evaporate for a range of dryness index values. Evapotranspiration is demand limited and cannot exceed potential evapotranspiration when the dryness index is less than 1 (dashed line); evapotranspiration is supply limited when the dryness index is greater than 1 (dotted line) and cannot exceed precipitation. Fig. 7 shows that evapotranspiration is demand limited in the eastern U.S., and it is supply limited in most of the western U.S.

The dashed and dotted lines (Fig. 8A) also coincide with the annual surplus model (see Table 1). For pre- 

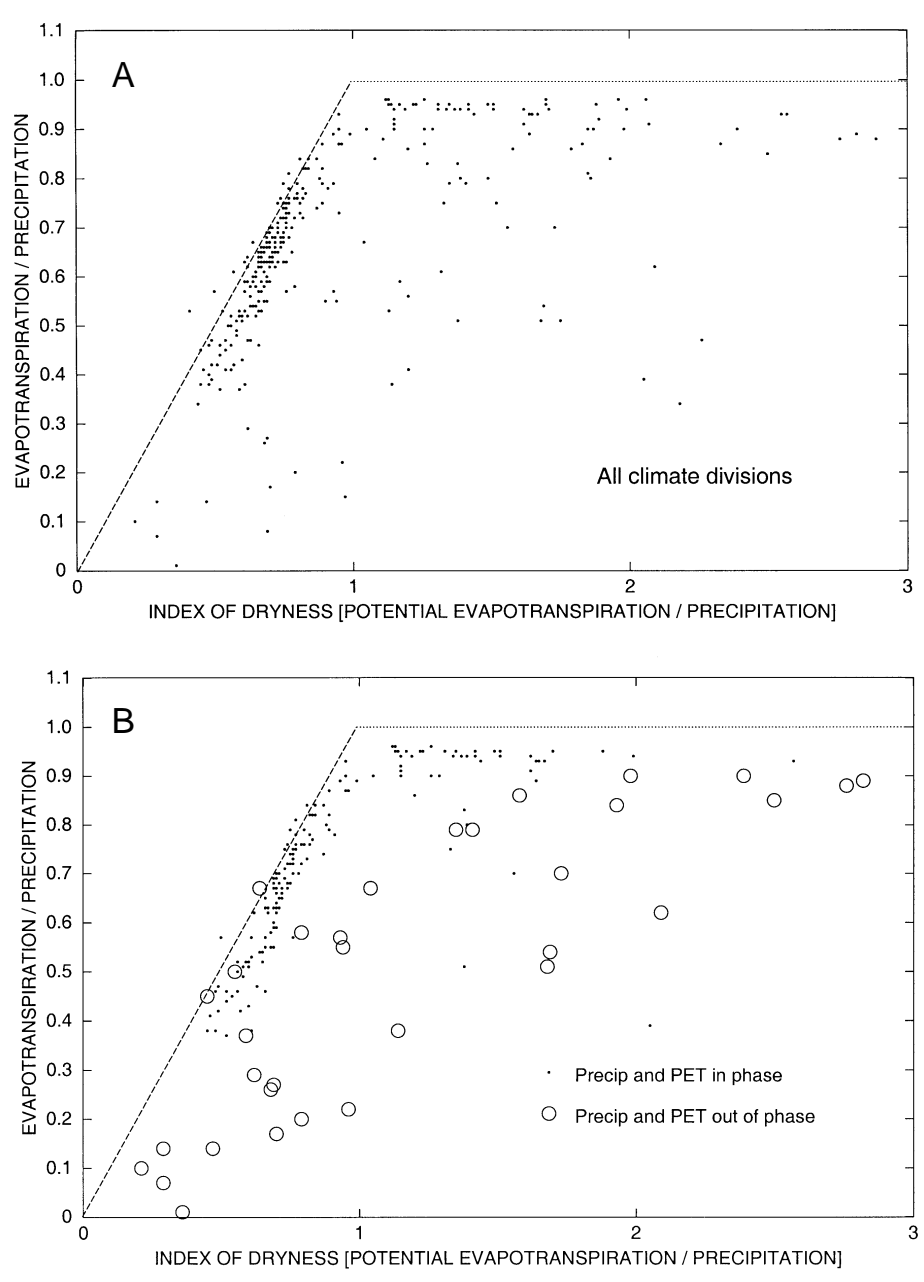

Fig. 8. Relation of the dryness index (potential evapotranspiration/ precipitation) to the ratio of actual evapotranspiration/precipitation for (A) all climate divisions and (B) climate divisions with precipitation and potential evapotranspiration in phase or out of phase. Potential evapotranspiration was estimated using the Hamon equation (Eq. 1). Actual evapotranspiration was estimated as measured mean annual precipitation minus measured mean annual runoff. For explanation of dashed and dotted lines see text

cipitation greater than potential evapotranspiration (dryness index less than 1), actual evapotranspiration is equal to potential evapotranspiration. For precipitation less than potential evapotranspiration (dryness index greater than 1), actual evapotranspiration is equal to precipitation.

Most of the climate divisions fall below the dashed and dotted annual surplus lines in Fig. 8A. This indicates that for most climate divisions, actual evapotranspiration is less than potential evapotranspiration in humid areas and less than precipitation in arid regions. Departure from the annual surplus upper boundary is caused by seasonality in supply and demand of water being out of phase. Climate divisions that plot near the annual surplus line have seasonal in-phase precipita- tion and potential evapotranspiration (Fig. 8B), whereas climate divisions that plot furthest from the annual surplus line have seasonal out-ofphase precipitation and potential evapotranspiration.

Even the most complex model considered here produced runoff estimates that were different from measured runoff in some parts of the country (Fig. 5E). The monthly surplus model with variable soil-moisture-storage capacity underestimated runoff particularly in mountainous regions of the western and northeastern U.S. These areas of underestimation correspond to climate divisions with high mean topographic slope values (Fig. 9A) (Slope was computed from a $1 \mathrm{~km}$ resolution digital elevation model [Verdin \& Greenlee 1996] using the average maximum technique [Burrough 1986] in a geographic information system). The correlation coefficient between the model underestimation and mean slope for the climate divisions is -0.61 . This may reflect some conceptual inadequacy in the model, or it may be due to input data errors.

Snow accumulation and melt are important processes in mountainous areas, and these concepts were not included in any of the models. Snow accumulation and melt have a large effect on the seasonal distribution of runoff, but including them in a model is unlikely to increase annual runoff. Snow accumulation and melt shift the season that water supply (precipitation) is available to satisfy demand (potential evapotranspiration) from one of lower demand (winter) to one of higher demand (spring and summer). Including snow accumulation and melt, therefore, tends to decrease, not increase, annual runoff.

Another explanation for the underestimation of runoff by the monthly surplus model with variable soil-moisture-storage capacity is underestimation of measured precipitation. The measured precipitation for the climate divisions may be less than the true precipitation in mountainous regions because most observation stations are at lower elevations. Orographic effects commonly increase precipitation at higher elevations, and these areas of high precipitation are under represented in the stations used to compute climate division precipitation. Evidence supporting this explanation is the observation that measured mean annual precipitation is less than measured mean annual runoff in some of the climate divisions in mountainous regions (data not shown).

A final possible reason for why the monthly surplus model with variable soil-moisture-storage capacity 
A

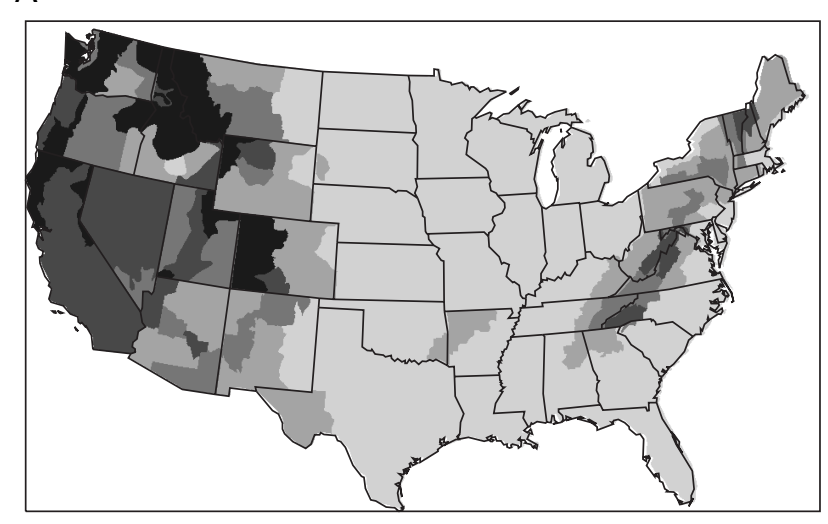

Mean slope (degrees)

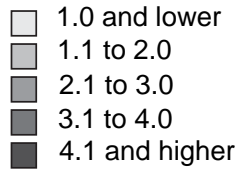

B

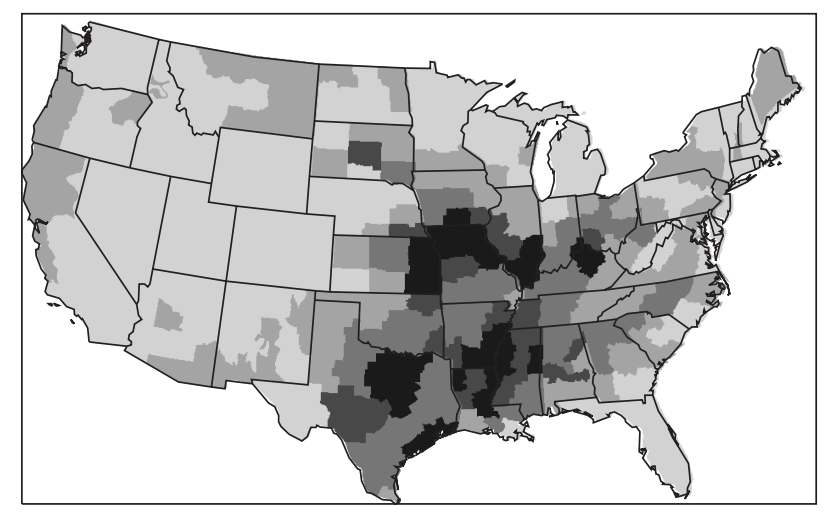

Precipitation intensity / Soil Permeability

$$
\begin{aligned}
& 0.10 \text { and lower } \\
& 0.11 \text { to } 0.20 \\
& 0.21 \text { to } 0.30 \\
& 0.31 \text { to } 0.40 \\
& 0.41 \text { and higher }
\end{aligned}
$$

Fig. 9. (A) Mean topographic slope for each climate division, and $(B)$ ratio of precipitation intensity to soil permeability for each climate division. Slope was calculated from $1 \mathrm{~km}$ resolution gridded elevation data for the conterminous U.S. Precipitation intensity was computed from a network of first-order meteorological stations, and soil permeability was derived from the U.S. Department of Agriculture's (1993) State Soil Geographic Data Base (STATSGO) data set

underestimated measured runoff is that the concept of infiltration-excess overland flow was not considered in any of the models. This concept states that runoff is generated when precipitation intensity exceeds the rate of infiltration into the soil; precipitation does not infiltrate into the soil and it directly becomes streamflow. A model that includes infiltration-excess overland flow would allow precipitation to bypass the soil, thereby reducing evapotranspira- tion and increasing the fraction of precipitation that becomes runoff.

Infiltration-excess overland flow is expected to be an important process in regions where precipitation intensity is high relative to soil permeability. The ratio of precipitation intensity to soil permeability (Fig. 9B) is low in the regions of the conterminous U.S. where the monthly surplus model with variable soil-moisturestorage capacity underestimated runoff (Fig. 5E). (Precipitation intensity was determined using daily precipitation data for 1040 stations in the conterminous U.S. [the data were obtained from the Climate Diagnostics Analysis and Information Center, Oak Ridge, Tennessee], and soil permeability was determined from STATSGO data [U.S. Department of Agriculture 1993].) This suggests that infiltration-excess overland flow probably is not an important process where the water-balance model underestimated runoff and including the concept in a water-balance model would not provide better estimates of annual runoff.

M ean annual runoff data have been used to evaluate the water-balance concepts in atmospheric general circulation models (e.g. Russell \& Miller 1990). The results reported in this paper, however, suggest that there are limitations in using mean annual runoff for evaluation of water- balance models. Only very simple concepts are needed to explain spatial variability in mean annual runoff across the conterminous U.S. Any model (even one with complex processes) that includes these simple water-balance concepts should provide good estimates of the spatial pattern of mean annual runoff. A comparison of predicted and measured patterns of mean annual runoff, therefore, only is testing the simple concepts in the model and is not providing a good evaluation of the more complex concepts in the model. These complex concepts may represent important physical processes, but they are not testable by comparison with mean annual runoff data.

The amount of conceptual complexity required in a hydrologic model depends on the temporal and spatial characteristics of the model application. In this study, the predicted hydrologic characteristic was mean annual runoff for climate divisions across the conterminous U.S. A runoff model applied at this level of temporal and spatial detail requires only simple concepts. Estimation of more detailed spatial and temporal characteristics (e.g. continuous simulation of runoff at short time steps for smaller areas) likely requires more complex models. The concepts included in a hydrologic model need to be commensurate with the temporal and spatial characteristics of the model application and need to be testable by direct comparison with measured data. The inclusion of non-testable complexity in hydrologic models may lead to misinterpretation of hydroclimatic processes. 


\section{CONCLUSIONS}

The results of this study indicate that on a continental scale the climatic water supply and demand primarily control the spatial distribution of mean annual runoff in the conterminous U.S. A Imost all of the information needed to explain the spatial distribution of mean annual runoff is contained in mean annual precipitation and potential evapotranspiration. However, soil-moisture- storage capacity together with seasonality in supply and demand are needed to estimate the correct magnitude of mean annual runoff. Water-balance models that contain more complexity than these concepts are unlikely to provide better estimates of mean annual runoff on a continental scale.

\section{LITERATURE CITED}

Budyko MI (1955) Atlas of the heat balance. Gridrometeoizdat, Leningrad

Budyko MI (1974) Climate and life. Academic Press, San Diego, CA

Burrough PA (1986) Principles of Geographical Information Systems for land resources assessment. Oxford University Press, New York

Gebert WA, Graczyk DJ, Krug WR (1987) Average annual runoff in the United States, 1951-80. Hydrol Invest Atlas HA-710, US Geological Survey, Reston, VA

Hamon WR (1961) Estimating potential evapotranspiration. J Hydraulics Div Proc Am Soc Civil Eng 87:107-120

Karl TR, Riebsame WE (1984) The identification of 10- to 20year temperature fluctuations and precipitation fluctuations in the contiguous United States. J Clim A ppl M eteorol 23:950-966

Karl TR, Williams CN J r, Young PJ , Wendland WM (1986) A model to estimate the time of observation bias associated with monthly mean maximum, minimum and mean temperatures for the United States. J Clim Appl M eteorol 25: $145-160$

Langbein WB (1949) Annual runoff in the United States. US Geological Survey Circular 52, Washington, DC

Leavesley GH, Lichty RW, Troutman BM, Saindon LG (1983) Precipitation-runoff modeling system user's manual. US

Editorial responsibility: Brent Yarnal,

University Park, Pennsylvania, USA
Geological Survey Water Resources Investigations Report 83-4238, Reston, VA

Lettenmaier DP, Wood EF, Wallis J R (1994) Hydro-climatological trends in the continental United States, 1948-88. J $C \lim$ 7:586-607

Lohmann D, Raschke E, Nijssen B, Lettenmaier DP (1998) Regional scale hydrology; I, formulation of the VIC-2L model coupled to a routing model. J Hydrol Sci 43:131-141

Milly PCD (1994) Climate, soil water storage, and the average annual water balance. Water Resour Res 30:2143-2156

Milly PCD, Eagleson PS (1987) Effects of spatial variability on annual average water balance. Water Resour Res 23: 2135-2143

Nash JE, Sutcliffe JV (1970) River flow forecasting through conceptual models: part $1-a$ discussion of principles. J Hydrol 10:282-290

Russell GL, Miller JR (1990) Global river runoff calculated from a global atmospheric general circulation model. J Hydrol 117:241-254

Strzepek KM, Yates DN (1997) Climate change impacts on the hydrologic resources of Europe: a simplified continental scale analysis. Clim Change 36:79-92

Thornthwaite CW (1948) An approach toward a rational classification of climate. Geogr Rev 38:55-94

U.S. Department of Agriculture (1993) State soils geographic data base (STATSGO). Miscellaneous Publication 1492, Soil Conservation Service

Verdin KL, Greenlee SK (1996) Development of continental scale digital elevation models and extraction of hydrographic features. In: Proceedings, third international conference/workshop on integrating GIS and environmental modeling, Santa Fe, N ew M exico, J anuary 21-26, 1996. National Center for Geographic Information and Analysis, Santa Barbara, CA, http://www.ncgia.ucsb.edu/ conf/SANTA FE CD-ROM/main.html

Wigmosta MS, Burges SJ (1997) An adaptive modeling and monitoring approach to describe the hydrologic behavior of small catchments. J Hydrol 202:48-77

Wilcox BP, Rawls WJ , Brakensiek DL, Wright J R (1990) Predicting runoff from rangeland catchments: a comparison of two models. Water Resour Res 26:2401-2410

Willmott CJ (1984) On the evaluation of model performance in physical geography. In: Gaile GL, Willmott CJ (eds) Spatial statistics and models. D Reidel, Dordrecht, p443-460

Xia J , O'Connor KM, Kachroo RK, Liang GC (1997) A non-linear perturbation model considering catchment wetness and its application in river flow forecasting. J Hydrol 200:164-178

Submitted: May 29, 1998; Accepted: October 21, 1998

Proofs received from author(s): J anuary 25, 1999 